\title{
Biochemical composition of red, green and brown seaweeds on the Swedish west coast
}

\author{
Joakim Olsson ${ }^{1}$ (D) $\cdot$ Gunilla B. Toth $^{2}$ (D) $\cdot$ Eva $^{\text {Albers }}{ }^{1}$ (D) \\ Received: 23 December 2019 / Revised and accepted: 30 April 2020 / Published online: 16 May 2020 \\ (C) The Author(s) 2020
}

\begin{abstract}
Seaweed biomass has the potential to become an important raw material for bio-based production. The aim of this study was to screen the overall composition of several seaweed species on the Swedish west coast, including some scarcely studied species, to provide fundamentals for evaluation of biorefining potential and to benchmark with already potentially industrially relevant species and commercially important land-based biomasses. Twenty-two common seaweed species (green, red, brown) were collected and the carbohydrate, ash, protein, water and metal contents were measured. Carbohydrate content varied between 237 and $557 \mathrm{~g} \mathrm{~kg}^{-1}$ dry weight (dw), making it the largest constituent, on a dry weight basis, of most species in the study. Ash, which is considered unwanted in biorefining, ranged between 118 and $419 \mathrm{~g} \mathrm{~kg}^{-1} \mathrm{dw}$ and was the largest constituent in several seaweeds, which were therefore considered unsuitable for biorefining. Protein content was most abundant in the red seaweeds but was generally low in all species $\left(59-201 \mathrm{~g} \mathrm{~kg}^{-1} \mathrm{dw}\right)$. High contents of several unwanted metals for processing or human consumption were found (e.g. aluminium, arsenic, copper, chromium and nickel), which need to be considered when utilizing seaweeds for certain applications. Potential targets for further biorefinery development mostly include species already known for their potential (Saccharina latissima, Laminaria digitata and Chondrus crispus) while some, such as Halidrys siliquosa and Dilsea carnosa, have not been previously noted. However, more detailed studies are required to explore biorefinery processes for these seaweeds, as well as how to potentially cultivate them.
\end{abstract}

Keywords Seaweeds $\cdot$ Biorefinery $\cdot$ Biochemical composition $\cdot$ Water content $\cdot$ Metals

\section{Introduction}

For a sustainable future, a transition to using biomass instead of fossil oil to produce fuels, chemicals, commodities and energy carriers is essential. Lately, interest has risen to utilise marine macroalgae (seaweeds) in biorefineries as it could provide biomass for bioenergy, as well as high-value products, with limited competition with food production (Jung et al. 2013; van Hal et al. 2014). In 2015, 29 million tonnes of seaweeds were cultured commercially (FAO 2015), mainly in Asia for utilisation as food and hydrocolloid production. Currently, only about 20

Eva Albers

albers@chalmers.se

1 Dept. of Biology and Biological Engineering - Industrial Biotechnology, Chalmers University of Technology, SE-412 96 Göteborg, Sweden

2 Dept. of Marine Sciences - Tjärnö, University of Gothenburg, SE-452 96 Strömstad, Sweden out of over 10,000 known seaweed species are cultivated (FAO 2015; Guiry and Guiry 2018), and overall knowledge on the biochemical composition of most seaweed species is lacking. Additionally, studies have shown significant intra-species variation in biomass composition depending on abiotic factors, such as light, temperature, minerals or season, many of which depend on where, geographically, the seaweed has been growing (Vilg et al. 2015; Nielsen et al. 2016). Hence, suitable species for future production of seaweed biomass could differ from place to place, and local knowledge is necessary to evaluate potential species on a regional basis. As such, identifying seaweed species with suitable compositions for biorefining while also having a sufficient growth rate for industrial-scale production in a given location should be a priority.

The ability to extract components and generate products efficiently for different applications from seaweed biomass has been largely seen to be related to the composition of a species (Harrysson et al. 2018). Like all biomass, seaweeds contain carbohydrates, proteins, lipids and ash as their major constituents. In general, a high carbohydrate content is required for utilisation in fermentation processes, assuming that 
the polysaccharides can be broken down into fermentable sugars. Fermentation of another type of biomass, lignocellulose, is now technically feasible with commercial-scale plants in operation using materials such as sugarcane bagasse and corn stover that are high in sugars $\left(670 \mathrm{~g} \mathrm{~kg}^{-1}\right.$ ww) and utilised to make various biochemicals (Kim and Day 2011; Troger et al. 2013; Chandel et al. 2018). However, developing pre-treatments that break down recalcitrant lignin, without generating inhibitory compounds, remains a significant challenge. Though discovered in at least one species (Martone et al. 2009), seaweeds do not generally contain lignin, which could make them an easier feedstock for fermentation than lignocellulosic biomass. However, pre-treatment has to be optimised for sugar release from the seaweed polysaccharides and the fermenting organism has to be able to utilise these monosaccharides. The isolation of valuable lipids and proteins could improve the economic feasibility of biorefineries but are generally a small fraction of the biomass and unlikely to be the main product. However, the lipids and proteins have nutritious profiles in seaweeds and if extracted and concentrated, they could add substantial value to the process (Baghel et al. 2016).

A high ash content is a significant challenge for developing seaweed biorefineries, which is the result of the seawater environment as well as their ability to passively and actively take up heavy metals (Hurd et al. 2014a). Alkali and alkaline earth metals and other ash components cause difficulties in processing and only few uses have been investigated (Magnusson et al. 2016). Another issue for processing of seaweeds is their high water content and any process requiring dry biomass will suffer from an energy burden, which needs to be compensated for to make a worthwhile process (Milledge et al. 2014).

Sweden has a long coastline and the Western region has the largest variety of seaweed species, but so far, almost no commercial exploration of seaweeds has been taken place in Sweden. It has been shown that $475 \mathrm{~km}^{2}$ is highly suitable for seaweed cultivation between Gothenburg and the Norwegian border, and several research projects are currently ongoing to investigate this potential closely for species such as Ulva lactuca and Saccharina latissima (Liljenström 2018; Thomas 2018). Environmental conditions that distinguish this region are lower salinity, compared with the open ocean, due to freshwater input from rivers and water originating from the low salinity Baltic Sea, as well as an almost complete lack of tides. Despite the unique conditions, the chemical composition of seaweeds from this area is largely unknown. For a species to possess potential for biorefinery processing, certain criteria need to be met, such as a suitable chemical composition and sufficient biomass availability. In this study, we have sampled 22 different native species from the sea around Kosterhavets National Park, located in the far north part of Sweden's west coast, to evaluate the macro-composition (total carbohydrates, total protein, ash and water content) and elemental composition $(\mathrm{C}, \mathrm{H}, \mathrm{N}, \mathrm{S}, \mathrm{P}$ and 17 heavy metals/ micronutrients). All species selected are commonly found in the sampling area and could therefore be assumed, given the right circumstances, to potentially be able to supply a biorefinery. Though beyond the scope of this study, this assumption needs to be closely investigated in future studies. The aim of this study was to screen the overall biochemical composition of a wide number of Swedish species and make appropriate comparisons with biomasses already utilised in bioprocesses to determine species with high potential. These data will provide the fundamental basis for evaluation of the potential for biorefining and future applied research on the identification and development of applications.

\section{Materials and methods}

\section{Seaweed collection}

In this study, 22 species of seaweed were collected within a few kilometres of Tjärnö Marine Laboratory (N58 $52.55^{\prime}$, E11 ${ }^{\circ}$ 08.77) adjacent to Kosterhavet National Park in northern part of Bohuslän region on the Swedish west coast during the summer of 2014 (Table 1). By utilising data from the environmental monitoring point Kosterfjorden (NR16) averaged for June, July and August for the period 2010-2014, some abiotic conditions for the area were estimated. Measurements that were reported below the detection limit were set as 0 for the reported averages (Havs- och vattenmyndigheten 2019). The collected species were identified based on morphological characteristics according to taxonomic literature for the area (Rueness 1977). Collected seaweeds were wiped with tissues or gently squeezed, depending on morphology, to remove excess water before freezing. At least 5 specimens of each species were pooled to minimise individual variation and only the holdfasts were not included in the pooled samples used for further preparation. For the larger species, all specimens were of similar size.

\section{Sample preparation and dry matter content}

Within a few weeks of sampling, the seaweed samples were homogenised in liquid nitrogen followed by freeze-drying (Heto Drywinner, Allerød, Denmark) for 3 days at $<0.05$ mbar with a cold trap temperature of $-55^{\circ} \mathrm{C}$. For the larger species, the entire sample taken was homogenised at once and mixed to allow representative sampling for water content measurements. By weighing triplicate dishes of seaweed before and after freezedrying, the water content was determined. The freeze-dried samples were roughly ground using a pestle and mortar and further homogenised in 5-mL grinding jars (frozen in liquid nitrogen for $1 \mathrm{~min}$ prior to each run) in a Tissue lyzer II (Qiagen, Germany) at $30 \mathrm{~Hz}$ for $1 \mathrm{~min}$ or longer when needed. The resulting fine powdered seaweed biomass was again freeze-dried overnight before storing the samples at -20 or $-80{ }^{\circ} \mathrm{C}$. 


\section{Ash analysis}

Porcelain crucibles were cleaned in a furnace at $550{ }^{\circ} \mathrm{C}$ for $3 \mathrm{~h}$ and cooled in a desiccator for at least $1 \mathrm{~h}$ prior to weighing. Approx. $100 \mathrm{mg}$ of biomass (exact weight recorded) was dried in the crucibles overnight at $105^{\circ} \mathrm{C}$. After cooling for at least $30 \mathrm{~min}$ in a desiccator, the crucibles were weighed and then subjected to $550^{\circ} \mathrm{C}$ for $3 \mathrm{~h}$ in a furnace. When the temperature had lowered to about $300{ }^{\circ} \mathrm{C}$, the crucibles were moved to a desiccator for at least $2 \mathrm{~h}$ before the final weight was recorded. The weight of biomass after $105{ }^{\circ} \mathrm{C}$ was used to calculate the ash content on a dry weight basis and each species was run in duplicate.

\section{Carbohydrate analysis}

All chemicals used in the carbohydrate analysis were purchased from Sigma or Fischer. Total hydrolysis of overnight dried biomass was performed according to Manns et al. (2014) in a two-step scheme with $72 \%$ sulphuric acid $\left(100 \mathrm{mg} \mathrm{mL}^{-1}\right)$ for $1 \mathrm{~h}$ at $30^{\circ} \mathrm{C}$ followed by dilution to $4 \%$ and incubation for $40 \mathrm{~min}$ at $120^{\circ} \mathrm{C}$. The hydrolysates were stored at $-80^{\circ} \mathrm{C}$ prior to analysis and each biomass was hydrolysed and analysed in duplicate. Concentrations of total carbohydrates were measured on the prepared hydrolysates using the MBTH-reagent (3-methyl-2-benzothiazolinone hydrazone hydrochloride hydrate) method of van Wychen and Laurens (2015) including neutralisation, but scaled down 2.5 times and with the last dilution performed in 96-well plates (Sarstedt). Absorbance was measured at $620 \mathrm{~nm}$ in a plate reader (FLUOstar Omega, BMG LABTECH, Germany). Glucose was used for the standard curve $\left(0-0.05 \mathrm{~g} \mathrm{~L}^{-1}\right)$ not only due to it being the most common sugar, but also because of it having a similar response factor to many major sugars in biomass (Anthon and Barrett 2002).

Since mannitol is not detected by the MBTH reagent, it was analysed separately for all brown seaweeds, by highperformance liquid chromatography (UltiMate 3000, Thermo Scientific, USA) coupled to a refractive index detector (IR-101, Shodex, Yokohama, Japan) using a standard curve $\left(0-1 \mathrm{~g} \mathrm{~L}^{-1}\right)$. For separation, a Rezex ROA-Organic Acid $\mathrm{H}+(8 \%)$ column $(300 \times 7.8 \mathrm{~mm}$, Phenomenex $)$ at $80{ }^{\circ} \mathrm{C}$ was used with isocratic elution consisting of $5 \mathrm{mM}$ $\mathrm{H}_{2} \mathrm{SO}_{4}$ at $0.8 \mathrm{~mL} \min ^{-1}$. These samples were not neutralised but filtered through $0.2-\mu \mathrm{m}$ nylon filters prior to analysis.

\section{Metals, CHN and protein analyses}

Elemental analysis was performed by ALS Scandinavia AB laboratory (Luleå, Sweden). The elements $\mathrm{Al}, \mathrm{As}, \mathrm{Ca}, \mathrm{Cd}, \mathrm{Co}$, $\mathrm{Cr}, \mathrm{Cu}, \mathrm{Fe}, \mathrm{Hg}, \mathrm{K}, \mathrm{Mg}, \mathrm{Mn}, \mathrm{Na}, \mathrm{Ni}, \mathrm{P}, \mathrm{Pb}, \mathrm{S}, \mathrm{Si}$ and $\mathrm{Zn}$ were measured in one sample per seaweed by induced coupled plasma and sector field mass spectroscopy (ISCP-SFMS) according to SS EN ISO 17294-1, 2 (mod) and EPA-method 200.8, while C, $\mathrm{H}$ and $\mathrm{N}$ were performed according to SS-EN 15104:2011/15407:2011. The protein content was calculated based on the nitrogen content of the elemental analysis using a nitrogen conversion factor of 5, as suggested by Angell et al. (2016) where an extensive discussion on the topic can be found.

\section{Statistics}

When appropriate, the standard deviation was calculated for the collected data, though in all cases, it is from technical variability and does not reflect natural variability. The mineral samples were run as singles for this analysis with the error given as expanded uncertainty defined by BIPM et al. (2008) with an inclusion factor of 2 . The principal component analysis (PCA) was performed using the software Origin to evaluate whether generalised conclusions regarding metal content could be drawn based on the seaweed being classified as green, red or brown. This was only done for the metals in Table 3 as this makes discussion of variation easier for those elements. The other data was either not suited for PCA (too many components were significant) or added no additional information.

\section{Results/discussion}

\section{Seaweed selection and sampling}

Seaweeds on the Swedish west coast were evaluated for potential utilisation in biorefinery processes by investigating the overall composition of 22 different species (Table 1) belonging to all groups of seaweeds (red, green and brown). For a species to be suitable for utilisation in biorefining in Sweden, some key criteria have to be met: (1) the species has to be native to the Swedish west coast (i.e. not invasive), (2) have the potential to provide a sufficient amount of biomass and (3) have a suitable composition. While the composition criteria were the focus of this work, the other criteria were kept in mind for the selection of species. Nativity is important from a permit perspective to not transgress regulation no 1143/2014 (EU) regarding prevention of the spread of alien species (European commission 2014). The potential to provide sufficient amounts of biomass includes both fast growth rate and length of a potential harvest season, which will not be investigated in this study. It is assumed by the commonality of the included species in Swedish waters that they could provide sufficient volumes of biomass for a biorefinery if given the right conditions and for species such as the Ulva sp., S. latissima, Laminaria digitata and other growth rates have been studied extensively under various conditions (Creed et al. 1998; Taylor et al. 2001; Handa et al. 2013). In addition, 
Table 1 Major constituents and collection dates of 22 species of green, red and brown seaweeds. Proteins were calculated from the nitrogen content using a factor of 5. Coverage is a sum of carbohydrates, mannitol, protein and ash. Italicised numbers mark the highest and the lowest valuse for each column and mean of technical replicates with \pm shows the standard deviation of these replicates, i.e. not biological variation. Samples were determined in a single replicate (protein), duplicate (ash, mannitol and carbohydrates) or triplicate (water content)

\begin{tabular}{|c|c|c|c|c|c|c|c|c|}
\hline Seaweed specie & & Collection date & Water content & Carbohydrates & Mannitol & Proteins & Ash & Coverage \\
\hline Chlorophyta & Cladophora rupestris & $1-7-2014$ & $741 \pm 20$ & $399 \pm 8$ & NA & 184 & $207 \pm 0$ & 79 \\
\hline & Cladophora sp. & $18,19,22-8-2014$ & $871 \pm 1$ & $348 \pm 25$ & NA & 139 & $365 \pm 1$ & 85 \\
\hline & Ulva intestinalis & $1-7-2014$ & $860 \pm 1$ & $367 \pm 31$ & NA & 90 & $319 \pm 2$ & 78 \\
\hline & Ulva lactuca & $1-7-2014$ & $824 \pm 1$ & $347 \pm 10$ & NA & 93 & $322 \pm 6$ & 76 \\
\hline Rhodophyta & Ahnfeltia plicata & $1-7-2014$ & $695 \pm 7$ & $302 \pm 9$ & NA & 201 & $232 \pm 7$ & 73 \\
\hline & Brogniartella byssoides & $21-8-2014$ & $858 \pm 1$ & $240 \pm 16$ & NA & 158 & $419 \pm 2$ & 82 \\
\hline & Ceramium sp. & $18-8-2014$ & $854 \pm 2$ & $352 \pm 37$ & NA & 158 & $328 \pm 1$ & 84 \\
\hline & Chondrus crispus & $1-7-2014$ & $746 \pm 8$ & $526 \pm 35$ & NA & 103 & $272 \pm 5$ & 90 \\
\hline & Cystoclonium purpureum & $1-7-2014$ & $866 \pm 1$ & $315 \pm 41$ & NA & 172 & $386 \pm 3$ & 87 \\
\hline & Delesseria sanguinea & $21-8-2014$ & $732 \pm 3$ & $259 \pm 20$ & NA & 183 & $312 \pm 0$ & 77 \\
\hline & Dilsea carnosa & $21-8-2014$ & $791 \pm 3$ & $477 \pm 28$ & NA & 152 & $240 \pm 0$ & 87 \\
\hline & Furcellaria lumbricalis & $1-7-2014$ & $762 \pm 6$ & $297 \pm 3$ & NA & 171 & $329 \pm 0$ & 80 \\
\hline & Rhodomela confervoides & $18-8-2014$ & $814 \pm 5$ & $340 \pm 17$ & NA & 148 & $322 \pm 1$ & 81 \\
\hline Phaeophyceae & Ascophyllum nodosum & $18-8-2014$ & $633 \pm 7$ & $317 \pm 17$ & $88 \pm 6$ & 59 & $202 \pm 0$ & 67 \\
\hline & Chorda filum & $1-7-2014$ & $876 \pm 2$ & $292 \pm 33$ & $80 \pm 2$ & 63 & $390 \pm 5$ & 83 \\
\hline & Desmarestia aculeata & $8-9-2014$ & $759 \pm 3$ & $301 \pm 101$ & $58 \pm 10$ & 115 & $254 \pm 2$ & 73 \\
\hline & Fucus serratus & $1-7-2014$ & $773 \pm 9$ & $287 \pm 21$ & $112 \pm 0$ & 71 & $203 \pm 4$ & 67 \\
\hline & Fucus vesiculosus & $1-7-2014$ & $765 \pm 24$ & $266 \pm 25$ & $81 \pm 1$ & 71 & $244 \pm 2$ & 66 \\
\hline & Halidrys siliquosa & $1-7-2014$ & $770 \pm 15$ & $237 \pm 67$ & $197 \pm 1$ & 79 & $176 \pm 7$ & 69 \\
\hline & Laminaria digitata & $19-8-2014$ & $699 \pm 14$ & $519 \pm 42$ & $127 \pm 4$ & 66 & $168 \pm 1$ & 88 \\
\hline & Saccharina latissima & $18-8-2014$ & $692 \pm 7$ & $557 \pm 14$ & $86 \pm 1$ & 69 & $118 \pm 3$ & 83 \\
\hline & Sphacelaria cirrosa & $18 / 19-8-2014$ & $834 \pm 1$ & $267 \pm 11$ & $24 \pm 0$ & 120 & $288 \pm 1$ & 70 \\
\hline
\end{tabular}

$N A$ not analysed, $w w$ wet weight, $d w$ dry weight

the optimal harvest time is not obvious even for extensively studied species as it depends on composition as well as settling of epiphytes and could therefore differ between locations (Vilg et al. 2015; Matsson et al. 2019). Hence, optimisation of harvest time and season requires more in-depth studies than provided here. Summer was chosen as collection time due to the favourable conditions for algae growth in Sweden during this time (elevated temperature and increased sunlight), which leads to more species being available for sampling this time of the year. Ability to be cultivated was not included as a criterion, as several of the species in this study have not previously been part of cultivation trials, though this study could motivate such studies. Ascophyllum nodosum was included, despite being slow growing as well as unlikely to be cultivatable, as it has been shown that wild beds can sustain harvest for many years (Guiry and Morrison 2013). A few species are common epiphytes and will probably not be able to provide large amounts of biomass in the natural habitat. However, they were included as they could be present in harvested biomass and many of them could have unknown properties of interest as they have not been investigated previously. Economic factors such as the amount of labour and costs related to cultivating or collecting biomass were not considered in the choice of species but could be substantial and require more in-depth studies. The samples of Cladophora and Ceramium were not distinguished to species level due to the number species of these families in the area which are only distinguishable by microscopy or genetic markers. However, these are quite opportunistic species and any cultivation in the ocean could become a mixture of species through biofouling/epiphytism as has been seen for both Ceramium and Cladophora species in aquaculture (Anderson et al. 1998; Pochon et al. 2015). Due to the amounts needed for analysis of these species, the only practical possible way of evaluation of samples collected from the environment is in bulk. It should be considered a starting point for further evaluation into specific species of these genera, for which monocultures in tanks are probably essential. To our knowledge, this is the first report of any part of the composition of Brogniartella byssoides and Sphacelaria cirrosa while the reports are scarce for several species studied.

It was decided that the samples would be analysed in bulk as a single pooled sample of at least 5 individuals. This choice 
was made to enable the screening of 22 species as well as to treat all species the same as biological replication is impossible for several species due to the small size of each individual. This obviously results in a loss of biological variation and gives an average composition. However, we believe that for screening species to evaluate their potential and find targets for future in-depth studies, this is a valid approach.

The abiotic factors dissolved inorganic nitrogen (DIN), phosphate and temperature for the sampling area were estimated from environmental monitoring data to have been $1.96 \mu \mathrm{mol} \mathrm{L}{ }^{-1}, 0.055 \mu \mathrm{mol} \mathrm{L}{ }^{-1}$ and $17{ }^{\circ} \mathrm{C}$ respectively. These levels of nutrients are within the normal ranges for coastal surface water of $0-34 \mu \mathrm{mol} \mathrm{L}{ }^{-1}$ for DIN and 0 $2 \mu \mathrm{mol} \mathrm{L}{ }^{-1}$ for phosphate (Hurd et al. 2014b). The salinity of the seawater in the area, in which the seaweeds were collected, ranges between 20 and 30\%o, depending on the depth and conditions at the time (University of Gothenburg 2014). The Swedish coast is also more or less atidal with a spring tide range of $0.3 \mathrm{~m}$ making the area different when it comes to for example zonation to nearby coastal areas in for example Scotland (Johannesson 1989). To pinpoint correlations between the specific abiotic factors and the seaweed composition in the sampling area, more extensive studies should be made and are not determined here.

\section{Biomass macro-composition}

The water content varied greatly between the different species ranging between 633 and $875 \mathrm{~g} \mathrm{~kg}^{-1}$ wet weight (ww) (Table 1), with similar ranges being seen in other studies (Maehre et al. 2014; Parjikolaei et al. 2016). While being high for biorefinery applications in general, the water content is still comparable with what has been found in for example sugarcane, i.e. 632-726 g kg ${ }^{-1}$ ww (Rae and Bonnet 2013). Hence, the water content does not rule out the use of seaweeds in a biorefinery, but it is a major obstacle to keep in mind when designing new processes utilizing seaweed. When making comparisons of the water content within this data set, one should have the differences in morphology in mind. For instance, Cladophora sp., which had one of the highest water contents, has a filamentous morphology where removing all excess water is difficult compared with the flat fronds or blades that e.g. A. nodosum and S. latissima possess. Factors such as morphology hence appear to have greater impacts on water content than phylum in this study, as high and low water contents are found in green, red and brown seaweeds.

The carbohydrate content among the species varied from low at $237 \mathrm{~g} \mathrm{~kg}^{-1}$ dry weight (dw) to fairly high at $557 \mathrm{~g} \mathrm{~kg}^{-1}$ $\mathrm{dw}$ (Table 2). Including the mannitol for the brown seaweeds, $S$. latissima and L. digitata had the highest carbohydrate content at about $650 \mathrm{~g} \mathrm{~kg}^{-1} \mathrm{dw}$, which is comparable with lignocellulosic biomass, such as wood, at about $650-750 \mathrm{~g} \mathrm{~kg}^{-1} \mathrm{dw}$ (Pettersen 1984). Both of these species are already known to be very promising for utilisation in a biorefinery, due to their high carbohydrate content of laminarin, alginate and fucoidan, but production is not currently believed to be economically feasible for low-value bulk applications (van den Burg et al. 2016). To our knowledge, this is the first analysis of the total carbohydrate content of Halidrys siliquosa. Specifically, its mannitol content was considerably higher than all other species at almost $200 \mathrm{~g} \mathrm{~kg}^{-1} \mathrm{dw}$, which is almost two times higher than the single previously reported value of mannitol content in this species (115.3 $\mathrm{g} \mathrm{kg}^{-1} \mathrm{dw}$ ) (Graiff et al. 2016). Among the red seaweeds, Dilsea carnosa and Chondrus crispus had the highest carbohydrate content at 477 and $526 \mathrm{~g} \mathrm{~kg}^{-1} \mathrm{dw}$, respectively. Chondrus crispus is well known for its use in the production of carrageenan, while D. carnosa has not been extensively studied but is known to contain partly desulfated lambda carrageenan as well as floridean starch (Zinoun et al. 1990). The carbohydrate content for the green seaweeds in this study was very similar between species at 347$399 \mathrm{~g} \mathrm{~kg}^{-1}$ and intermediate compared with the red and brown species groups.

Protein was a minor component and the content varied between 59 and $201 \mathrm{~g} \mathrm{~kg}^{-1} \mathrm{dw}$. The highest protein content was seen in the red seaweed Ahnfeltia plicata, but it is still low compared with terrestrial vegetable protein sources, such as soybean at $400 \mathrm{~g} \mathrm{~kg}^{-1} \mathrm{dw}$ (Karr-Lilienthal et al. 2006). Despite the low content, seaweeds could be considered potential sources of protein for human and animal nutrition as the fraction of essential amino acids is high in most species (Fleurence 2004).

The ash content of the seaweeds was found to be between 118 and $419 \mathrm{~g} \mathrm{~kg}^{-1} \mathrm{dw}$, which is very high compared with for example wood at approximately $1 \%$ (Klass 1998). One factor behind this is the passive uptake of ions, by interactions with charged polysaccharides in the seaweed cell wall, as well as active uptake (Hurd et al. 2014a). Another contributor to the ash content is the salt in the residual seawater associated with the biomass after collection.

In general, the results presented in this study are in overall agreement with the available literature on the composition of seaweeds from Northern Europe, though some discrepancies can be found. Comparisons between studies on seaweed composition can be difficult due to methodological differences and due to the fact that composition varies seasonally and geographically (Fiset et al. 2017) giving dissimilarities, which roots can only be speculated at. One example is the fairly new MBTH-reagent method for measuring sugars, which has been shown to be better than the classic phenolsulphuric acid method for algal carbohydrates (Van Wychen et al. 2017) but is not yet extensively used. Protein determination is known to be troublesome in seaweeds when utilising nitrogen to protein conversion factors as some seaweeds are known to accumulate nitrate (Young et al. 2007), and the amounts of inorganic and organic nitrogen are known to differ 


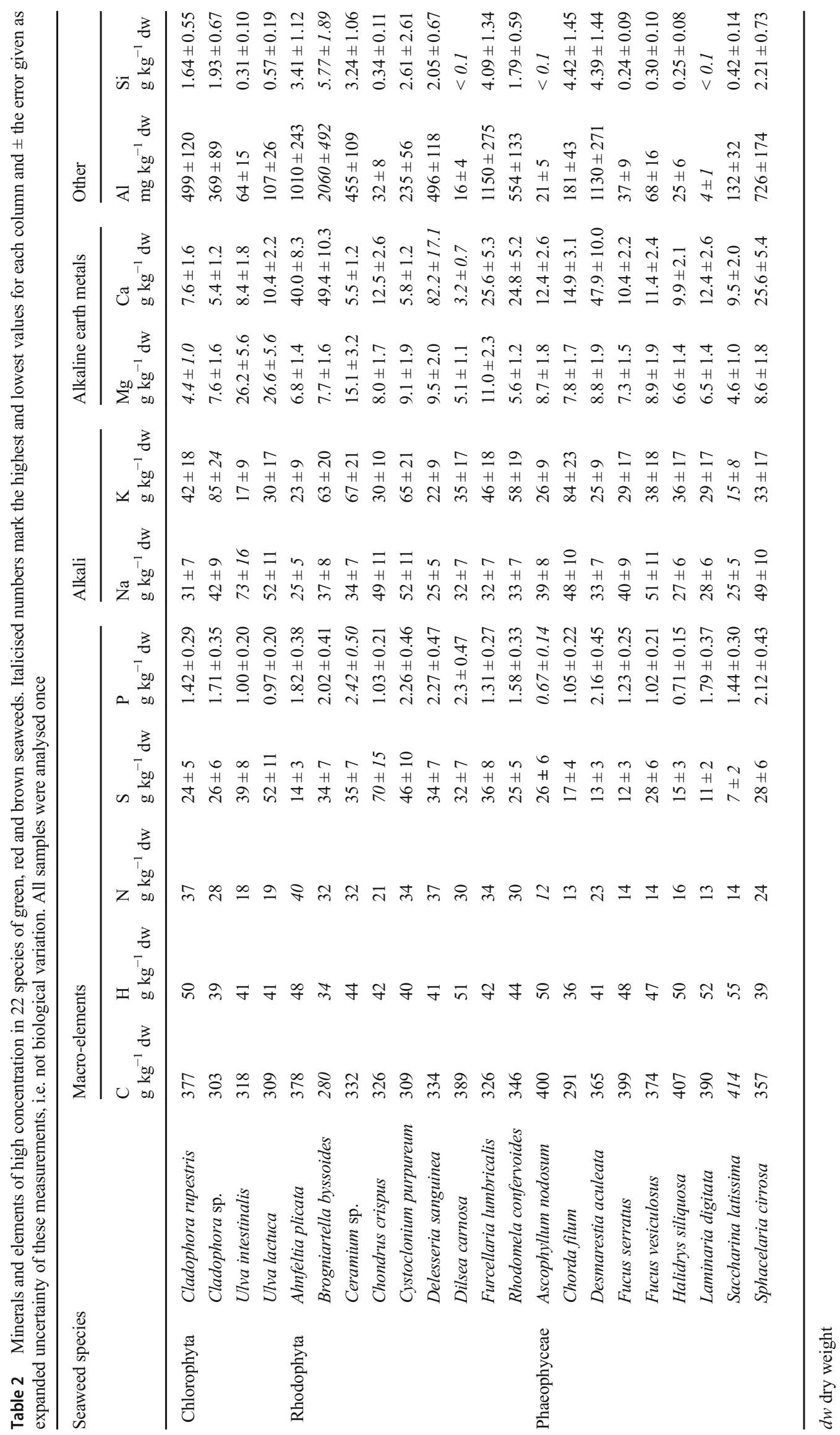


depending on growth locality and season (Hurd et al. 2014b; Marinho and Holdt 2017). Despite some species in this study having individual factors determined (Biancarosa et al. 2018), the universal seaweed factor of 5 was chosen as it was calculated as an average of many seasons, species and localities as discussed in Angell et al. (2016). In addition, using the same factor for all species avoids the introduction of biases between novel species and those previously studied and allows comparison within the study. Variability caused by seasonality and environmental conditions is well documented for seaweeds (Galland-Irmouli et al. 1999; Schiener et al. 2015; Vilg et al. 2015; Manns et al. 2017), but which causes variability compared with similar studies for the investigated species cannot be elucidated with the methodological approach in this study.

Maehre et al. (2014) characterised, among other components, water, proteins (as total amino acids) and ash in 10 species along the Norwegian coast and their results for L. digitata, Fucus vesiculosus, Cladophora rupestris, Ulva intestinalis and U. lactuca could be compared with the results in this study. In another Norwegian study, Biancarosa et al. (2017) measured protein (as total amino acids) for several species. In both studies, discrepancies can be found, mostly in the protein content, but values are similar for the species in common. Parjikolaei et al. (2016) did an estimation of protein using conversion factors in Danish waters and found similar values to this study, when data was converted to the same factor as in this study. They also studied water and ash content, for which C. crispus and D. carnosa contained similar amounts, while A. plicata, Delesseria sanguinea and Furcellaria lumbricalis contained less ash. In general, the carbohydrate contents of the seaweed species investigated in this study compare very well to values reported in the literature for red and brown seaweeds (Morrissey et al. 2001; Manns et al. 2017), while for the green $U$. lactuca, variable carbohydrate contents have been reported worldwide such as $240 \mathrm{~g} \mathrm{~kg}^{-1}$ in the Netherlands by Bikker et al. (2016) and $460 \mathrm{~g} \mathrm{~kg}^{-1}$ in Egypt by Khairy and El-Shafay (2013) as compared with our measured $347 \mathrm{~g} \mathrm{~kg}^{-1}$. The observed discrepancies indicate the effects of environmental conditions and seasonality on composition, which will be important to study in detail for evaluating the full potential of promising species in this study, especially if the content of certain components should be maximised.

The compounds analysed in this study (carbohydrates, mannitol, proteins and ash) covered between 70 and $90 \%$ of the total content of the biomasses (Table 1), indicating that there were not only substantial amounts of other compounds not determined in the seaweeds, but also great variation in the fraction of other components than the common main constituents of seaweeds. One of the classes of compounds which were not included in this study was lipids as it is normally less than $40 \mathrm{~g} \mathrm{~kg}^{-1} \mathrm{dw}$ (Overland et al. 2019). For some species included in this study, the lipid content is known from other studies, such as the previously mentioned studies from Norway and Denmark. Laminaria digitata, F. vesiculosus, C. rupestris, U. intestinalis and U. lactuca contained 8.8$35 \mathrm{~g} \mathrm{~kg}^{-1} \mathrm{dw}$ (Maehre et al. 2014) and the red species Ahnfeltia plicata, Chondrus crispus, Delesseria sanguinea, Dilsea carnosa and Furcellaria lumbricalis collected in Denmark contained $10-13 \mathrm{~g} \mathrm{~kg}^{-1} \mathrm{dw}$ (Parjikolaei et al. 2016). Another class of compounds left out was phlorotannins and other phenolic compounds, which can be abundant in brown seaweeds. For H. siliquosa, the phenolic content has been measured to be $18 \%$ (total phenolics $\mathrm{dw}^{-1}$ ), and up to $30 \%$ in some other brown seaweeds (Stiger-Pouvreau et al. 2014). The lack of phenolics data is likely why the two Fucus species, $F$. vesiculosus and $F$. serratus, had the lowest total mass balances (less than 70\%) as 20\% total phenolics have been observed in this family (Stiger-Pouvreau et al. 2014). Other compounds that also could contribute to closing the mass balance are sugar alcohols and nucleic acids.

\section{CHN, minerals and metals}

Both the carbon and hydrogen content were highest in S. latissima at 404 and $55 \mathrm{~g} \mathrm{~kg}^{-1} \mathrm{dw}$ respectively, while the sulphur content was the lowest at $7.47 \mathrm{~g} \mathrm{~kg}^{-1} \mathrm{dw}$ (Table 2). This was expected due to its low ash content and that the only polysaccharide that is sulphated in brown seaweeds is fucoidan, which constitutes a small part of the biomass (20$100 \mathrm{~g} \mathrm{~kg}^{-1} \mathrm{dw}$ ). Contrastingly, sulphated polysaccharides in green and red seaweeds, such as ulvan (80-290 $\left.\mathrm{g} \mathrm{kg}^{-1} \mathrm{dw}\right)$ and carrageenan (220-880 $\left.\mathrm{g} \mathrm{kg}^{-1} \mathrm{dw}\right)$, are generally abundant (Lahaye and Robic 2007; Holdt and Kraan 2011; Rioux and Turgeon 2015). Consistently, the sulphur content was especially high in the red and green seaweeds, reaching as high as $70 \mathrm{~g} \mathrm{~kg}^{-1} \mathrm{dw}$ in C. crispus, compared with the brown seaweeds with the highest found in F. serratus at $28.3 \mathrm{~g} \mathrm{~kg}^{-1} \mathrm{dw}$. For all the seaweed species, the sulphur content is considerably higher than common land-based biomasses such as wheat straw at $3.2 \mathrm{~g} \mathrm{~kg}^{-1} \mathrm{dw}$ (Niu et al. 2014). The high sulphur content also results in a lower energy content, which is also significantly affected by low carbon content caused by the relatively high ash content in seaweeds. Even the carbon content in S. latissima is low compared with that in wood, where values close to $500 \mathrm{~g} \mathrm{~kg}^{-1} \mathrm{dw}$ are common (Pettersen 1984).

In general, alkali and metal content seems to correlate well with low ash as seen by $L$. digitata, S. latissima and $D$. carnosa having the lowest contents of several elements in Tables 2 and 3. This is especially true for alkali where the brown seaweeds showed down to $40 \mathrm{~g} \mathrm{~kg}^{-1}$ of summarised sodium and potassium (S. latissima), whereas the lowest for the greens was as high as $73 \mathrm{~g} \mathrm{~kg}^{-1}$ (C. rupestris). The elemental compositions of seaweeds from Scandinavia are largely unknown, but this study shows values of the same order of magnitude for 11 common species and 9 elements to the 


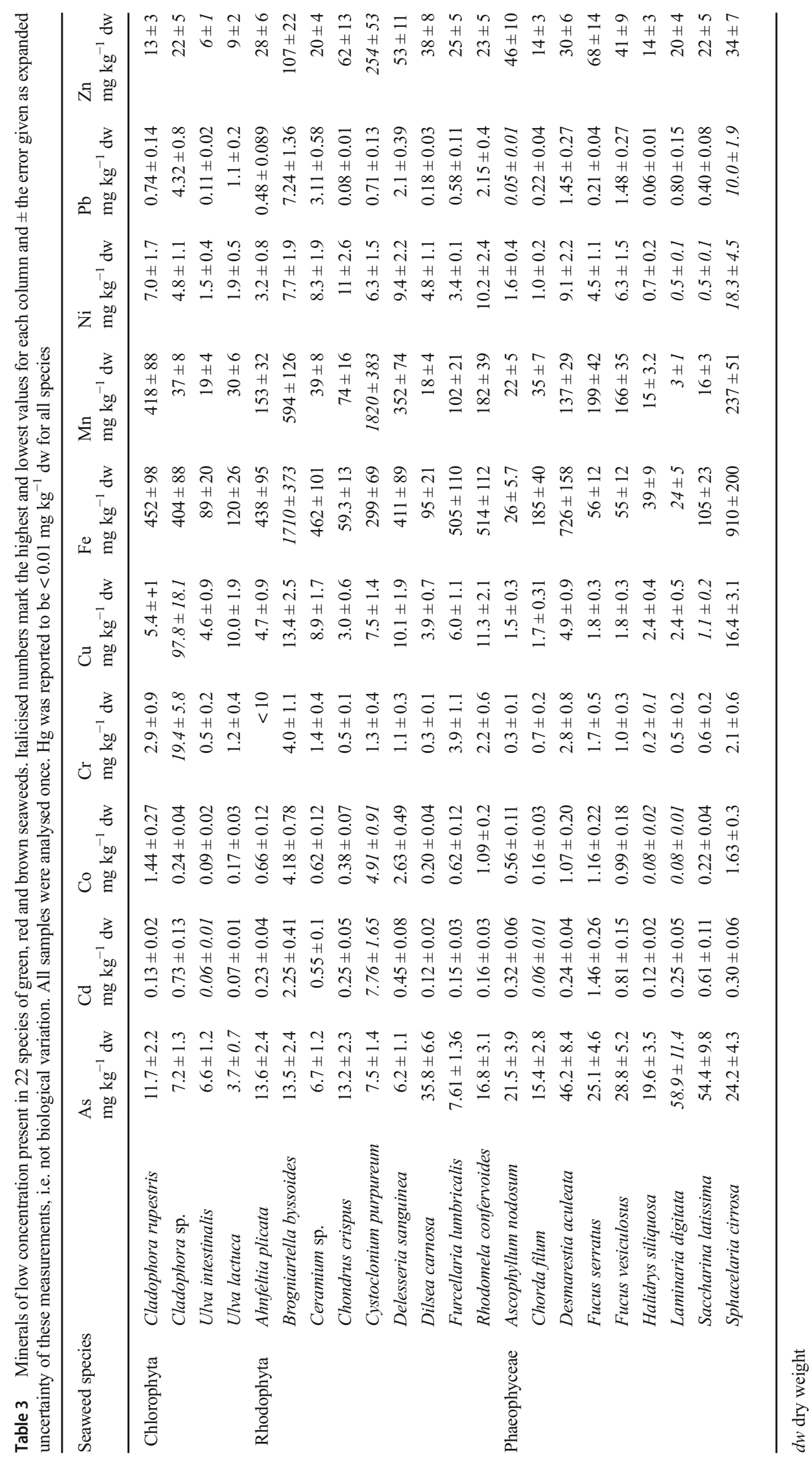


recent study by Biancarosa et al. (2018). Also in the study on Scottish $S$. latissima and $L$. digitata, the 9 analysed elements in common showed the same magnitude with the exception that the $\mathrm{Al}$ and $\mathrm{Fe}$ levels in $L$. digitata were about 10 times lower in our samples (Schiener et al. 2015). It should be noted that no rinsing was performed of the seaweeds in this study which does give some influence of seawater in the values reported for species where excess water was difficult to remove (filamentous seaweeds). However, we argue that rinsing would also affect the levels of minerals as rinsing with deionised water would likely remove minerals adhered to the surface of the seaweeds, though the differences caused by these approaches need to be investigated further. As rinsing with freshwater, for large-scale biorefinery applications, is questionable from a sustainability perspective, it was chosen to remove surface water by squeezing gently or wiping with tissues.

In Table 3, the heavy metals and minerals of lower concentration are listed. The data is discussed here mainly from a human consumption perspective due to the inherent difficulty in predicting where the minerals accumulate in hypothetical biorefinery concepts. While not being a focus of the study, the levels of these elements suggest both risks and potential benefits from consuming seaweeds. The cadmium content of food supplements consisting exclusively or mainly of dried seaweed is restricted in the EU to $3 \mathrm{mg} \mathrm{kg}^{-1}$ and this limit is only exceeded in Cystoclonium purpureum. Lead in seaweeds is regulated for consumption as vegetables to a maximum content of $0.1 \mathrm{mg} \mathrm{kg}^{-1}$ wet weight (ww) (European commission 2006). This level is exceeded (calculation not shown) by more than half the seaweeds in this study and only Ulva intestinalis, C. crispus, C. purpureum, D. carnosa, A. nodosum, C. filum, F. serratus and $H$. siliquosa would be allowed for utilsation in food as analysed here. Notably, S. latissima and L. digitata, which are common in research cultivations in Europe, are above at 0.12 and $0.24 \mathrm{mg} \mathrm{kg}^{-1} \mathrm{ww}$, respectively. However, metal content in seaweeds is known to vary by factors such as size, age and nutritional state (Hurd et al. 2014a), which was not considered in this study. Hence, further study is needed to determine if these levels can be avoided by more selective sampling or cultivation.

The levels of arsenic are also concerning as the range of $3.7-58.9 \mathrm{mg} \mathrm{kg}^{-1} \mathrm{dw}$ seems very high in comparison with legislative limits, though in line with previous findings (Biancarosa et al. 2018). However, the inorganic arsenic is the more toxic form and, while there is no restricted limit for seaweeds, it is restricted in for example white rice to less than $0.20 \mathrm{mg} \mathrm{kg}^{-1}$ wet weight (European commission 2006). Despite the lowest total arsenic in this study being as high as $0.66 \mathrm{~m} \mathrm{~kg} \mathrm{k}^{-1} \mathrm{ww}$, the form of the arsenic was not investigated, and it is unknown whether the investigated species are close to the restricted levels of inorganic arsenic or not. However, in Biancarosa et al. (2018), the content of inorganic arsenic was found to be particularly high in $H$. siliquosa at $10 \%$ of total arsenic, which would translate to $2 \mathrm{mg} \mathrm{kg}^{-1} \mathrm{dw}$ or $0.45 \mathrm{mg} \mathrm{kg}^{-1}$ ww in this study. Likely, seaweeds with this amount of inorganic arsenic would not be allowed for consumption judging by the available limits for other products. This clearly motivates future studies investigating the inorganic arsenic levels in Swedish seaweeds. Another toxic element facing heavy regulation is mercury. However, mercury was reported to be $<0.01 \mathrm{mg} \mathrm{kg}^{-1}$ for all the species analysed and thus, it will be of low concern for these species, at least from this part of Sweden. Some of the other elements measured are essential minerals in a healthy diet, i.e. $\mathrm{P}, \mathrm{Fe}, \mathrm{Ca}, \mathrm{K}$, $\mathrm{Cu}, \mathrm{Cr}, \mathrm{Mg}, \mathrm{Mn}$ and $\mathrm{Zn}$ (Tables 2 and 3). For example, to ingest the recommended daily intake of copper at $0.9 \mathrm{mg}$ set by the Nordic countries (Nordic Council of Ministers 2012), one would be required to eat between $71 \mathrm{~g}$ and $2.6 \mathrm{~kg}$ of wet seaweed depending on the species, not considering accessibility of copper from seaweed biomass. This hints at the large variation among the studied species and a potential market could be as dietary supplements for people deficient in certain minerals.

Principal component analysis of the elements in Table 3, visualised in Fig. 1, does not show any systematic difference between the different phyla. While the brown seaweeds mostly group in the lower left, two species do not and the only axis

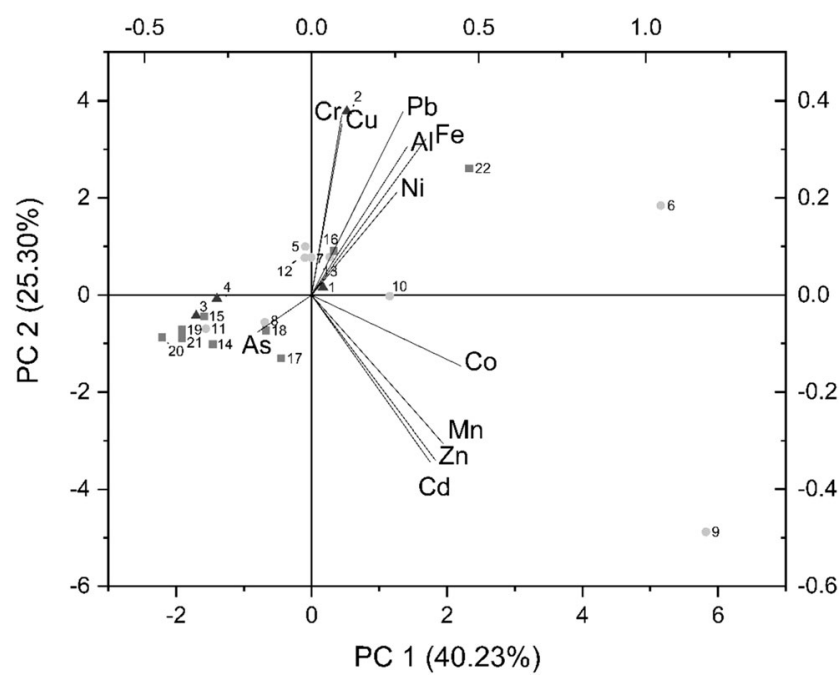

Fig. 1 PCA over the metal content of 22 species of green, red and brown seaweeds. Five components were extracted and these accounted for $96.8 \%$ of the variance ( 1 and 2 reflects $65.5 \%$ ) and each vector represents one element. The dots are colour coded in receding greyness for green (triangles), red (circles) and brown (squares) seaweeds, and numbers refer to single species as follows: (1) Cladophora rupestris, (2) Cladophora sp., (3) Ulva intestinalis, (4) Ulva lactuca, (5) Ahnfeltia plicata, (6) Brogniartella byssoides, (7) Ceramium sp., (8) Chondrus crispus, (9) Cystoclonium purpureum, (10) Delesseria sanguinea, (11) Dilsea carnosa, (12) Furcellaria lumbricalis, (13) Rhodomela confervoides, (14) Ascophyllum nodosum, (15) Chorda filum, (16) Desmarestia aculeate, (17) Fucus serratus, (18) Fucus vesiculosus, (19) Halidrys siliquosa, (20) Laminaria digitata, (21) Saccharina latissima, (22) Sphacelaria cirrosa 
going to the lower left quadrant is arsenic. Considering the lack of grouping as well as the low impact of the arsenic axis, it cannot be argued that brown seaweeds have a systematically higher arsenic content. In fact, the low impact of the arsenic axis, indicating lack of variation, together with the actual values in Table 3 shows that regardless of species, there will be a considerable amount of arsenic in seaweeds. Conversely, the toxic heavy metals cadmium and lead have highly impactful axes. It can therefore be argued that they could be minimised by choosing species in the opposite quadrant to the direction of these axes and not e.g. C. purpureum or $S$. cirrosa, which deviate strongly from the mean. Other species that deviate strongly are Cladophora sp. with its chromium and copper content, and B. byssoides with high levels in several of the studied components. However, one also has to consider that the seaweeds used in this study are from a single location and at a single time point and might not depict the full picture of metal variation in seaweeds.

Interestingly some groupings within seaweed families are seen as the two Ulva species are in close proximity and the same goes for the two Fucus species in the study. This could indicate a systematic difference caused by the properties shared among closely related species. The existence of such a difference is contradicted by the two Cladophora species, which are not in close proximity to each other, and more species from these families would be needed to draw any conclusions regarding the existence of a systematic difference.

\section{Potential applications}

To a large extent, the pros and cons of utilizing seaweeds for biorefinery found in this study are in line with earlier studies. Alkali and alkaline earth metals are always expected to be a large fraction of seaweed biomass and could cause fouling of combustion/boiler systems (Skoglund et al. 2017). Additionally, for applications in combustion, the nitrogen and especially sulphur content are likely to cause corrosive emissions. Furthermore, the potassium content strongly affects the product yields in pyrolysis and together with other inorganic compounds in seaweeds, it also affects the specific surface area of the produced char (Milledge et al. 2014). However, some of these minerals could be washed away and concentrated to a seaweed salt which would make processing easier (Magnusson et al. 2016). Combustion and pyrolysis generally require dry biomass and the net gain in energy would be lowered by the drying process required to dry the wet seaweeds.

Historically, seaweeds have been used as fertilizers but not all species in the present study are suitable for this application. For example, B. byssoides and C. purpureum exceed the $1.5 \mathrm{mg} \mathrm{kg}^{-1} \mathrm{dw}$ threshold of cadmium allowed for biofertilizer and Cladophora sp. exceeds that of copper for eco- certified compost and digestate at $70 \mathrm{mg} \mathrm{kg}^{-1} \mathrm{dw}$ (European commission 2008). The level of phosphorus is also much too low for direct use in a large scale, as $20 \mathrm{~kg}$ of phosphorus per hectare is a normal dosing which is approximately $8000 \mathrm{~kg}$ of fresh Ceramium sp. As the average Swedish farm is 40 ha, the needed amounts required per farm become unfeasible ( $320,000 \mathrm{t}$ ). This scenario is similar for nitrogen. In addition, this is a relatively low-value application of the biomass. One approach which has been demonstrated to extract and concentrate nitrogen and phosphorus in an aqueous form from seaweeds is hydrothermal liquefaction (HTL) (Raikova et al. 2017). Additionally, this method extracts energy in the form of a bio-oil and a gas phase from wet material, avoiding the issue with drying, and has been shown to work on a variety of seaweeds (Raikova et al. 2017).

Another potential route is a refinery based on converting the sugars by fermentation. Through fermentation by microorganisms, most biomolecules could be produced, but topical examples are ethanol and succinate (Hou et al. 2015; Marinho et al. 2016). Like the HTL, the biomass does not have to be dry as processings before fermentation are wet processes. However, these processes have to degrade the complex polysaccharides in seaweed into monomeric sugars and the monomers have to be utilizable by the production organism. The concept has been demonstrated for all phyla of seaweeds (Yanagisawa et al. 2013), but ethanol, currently, has too low value to be profitable even in combination with alginate production, since the current alginate market is too small and would quickly saturate (Konda et al. 2015). Efforts have been made to enable fermentation of laminarin and mannitol as well as alginate (Enquist-Newman et al. 2014), which could improve the economic case for seaweeds as a feedstock for fermentation. As the usefulness, for fermentation, of the studied species depends on how easily degradable the polysaccharides are as well as what monosaccharides are present, it is difficult to put a number on how large the sugar fraction must be for them to be a useful feedstock. However, lignocellulosic biomasses are also complex mixtures of polysaccharides (cellulose and hemicellulose) and, despite difficulties with profitability, there are biorefineries producing ethanol, succinic acid, glucaric acid and many other biochemicals (Chandel et al. 2018). The feedstock varies in commercial refineries, but among the more common are sugarcane bagasse and corn stover, with a sugar content around $670 \mathrm{~g} \mathrm{~kg}^{-1} \mathrm{dw}$ (Kim and Day 2011; Troger et al. 2013). Only S. latissima and $L$. digitata are really close to these levels, when including the mannitol, displaying why the economics of utilizing seaweeds for ethanol is difficult. Chondrus crispus and D. carnosa are somewhat close as well and increased need of biochemicals from fermentation could validate further investigations into these species as well. A common trait among these species is also that they had a low ash content indicating that there are more than sugars to be extracted into potentially valuable side streams. 
A biorefinery based on fractionation could also isolate protein and lipid fractions, which are likely to be of high value in most seaweeds due to the nutritious profile (Harrysson et al. 2018). However, due to its low content in the biomass, it likely needs to be combined with products based on the more abundant components of seaweeds. The low-value applications discussed above have considerable drawbacks, while giving little value, and thus, the most likely path for commercialisation of seaweeds is connected to recovery of high-value products in biorefineries.

An unexpected find in this study was the mannitol content of $H$. siliquos $a$ at almost $200 \mathrm{~g} \mathrm{~kg}^{-1} \mathrm{dw}$. The demand for mannitol is predicted to increase in the future, and it has applications within food, pharmaceuticals and other areas (Grand View Research 2016). This potentially makes $H$. siliquosa an interesting species for future studies to see if its mannitol content varies with the seasons and could be further improved.

Along the Swedish west coast, there are certainly additional unstudied species, out of the about 300 species present, with potential in biorefining to explore in future investigations. The results of this study compare well to other studies, but detecting any geographical, population or seasonal differences in composition is beyond its scope. For the future, it would be interesting looking into monosaccharide profiles of the seaweeds as many monosaccharides present in seaweeds, such as the rare uronic acid and iduronic acid, and their diverse polysaccharides could have wide industrial uses in food, chemical or medical areas (Holdt and Kraan 2011).

\section{Conclusion}

This study has shown the overall biochemical composition of 22 species of seaweed common on the Swedish west coast. The results showed that the species that are widely being studied for utilisation in biorefining, such as S. latissima, L. digitata and C. crispus, are also among the most promising species on the Swedish west coast. However, the data revealed species previously unexplored for biorefinery, such as $H$. siliquosa, if the interest lies in mannitol, and D. carnosa, for future research. But in general, few seaweeds are obviously unsuitable for biorefinery and the deciding factors for which species might be utilised in the future likely lie in their cultivability and productivity, as well as the incurred costs. However, few species reach the same levels of commercial sources of sugars for fermentation and no species reaches those for the common protein source soy making the profitability questionable for these utilisations. Before seaweeds can be utilised for food, feed and bioenergy, robust processes based on fractionation or recovery of high-value compounds, that deal with the discussed shortcomings of this productive biomass, need to be developed and shown to be economically feasible. While doing this, one has to keep in mind where the heavy metals accumulate and have a strategy for how they are to be dealt with in bio-processing operations. In summary, our work has found new and interesting species with potential for biorefining in Sweden and hopefully this data will be used to motivate future studies which can make such an industry a reality.

Acknowledgements Open access funding provided by Chalmers University of Technology. We thank our dear friend and colleague Viktor Andersson, previously at Chalmers University of Technology, for discussions within our joint project, and may he rest in peace. This paper is dedicated to you and we believe you would have been proud of the outcome of the project. We would also like to thank our colleagues at Göteborg University, Gunnar Cervin and Göran Nylund, for help with collecting the seaweeds.

Author's contribution All authors have agreed to authorship and submission for peer review.

Funding information This project was funded by the cooperation program "Preem and Chalmers towards a sustainable refinery" between Preem and Area of Advance-Energy at Chalmers.

\section{Compliance with ethical standards}

Conflict of interest The authors declare that they have no conflict of interests.

Open Access This article is licensed under a Creative Commons Attribution 4.0 International License, which permits use, sharing, adaptation, distribution and reproduction in any medium or format, as long as you give appropriate credit to the original author(s) and the source, provide a link to the Creative Commons licence, and indicate if changes were made. The images or other third party material in this article are included in the article's Creative Commons licence, unless indicated otherwise in a credit line to the material. If material is not included in the article's Creative Commons licence and your intended use is not permitted by statutory regulation or exceeds the permitted use, you will need to obtain permission directly from the copyright holder. To view a copy of this licence, visit http://creativecommons.org/licenses/by/4.0/.

\section{References}

Anderson BC, Smit AJ, Bolton JJ (1998) Differential grazing effects by isopods on Gracilaria gracilis and epiphytic Ceramium diaphanum in suspended raft culture. Aquaculture 169:99-109

Angell AR, Mata L, de Nys R, Paul NA (2016) The protein content of seaweeds: a universal nitrogen-to-protein conversion factor of five. $J$ Appl Phycol 28:511-524

Anthon GE, Barrett DM (2002) Determination of reducing sugars with 3methyl-2-benzothiazolinonehydrazone. Anal Biochem 305:287289

Baghel RS, Trivedi N, Reddy CRK (2016) A simple process for recovery of a stream of products from marine macroalgal biomass. Bioresour Technol 203:160-165

Biancarosa I, Belghit I, Bruckner CG, Liland NS, Waagbo R, Amlund H, Heesch S, Lock EJ (2018) Chemical characterization of 21 species of marine macroalgae common in Norwegian waters: benefits of and limitations to their potential use in food and feed. J Sci Food Agr 98: 2035-2042 
Biancarosa I, Espe M, Bruckner CG, Heesch S, Liland N, Waagbo R, Torstensen B, Lock EJ (2017) Amino acid composition, protein content, and nitrogen-to-protein conversion factors of 21 seaweed species from Norwegian waters. J Appl Phycol 29:1001-1009

Bikker P, van Krimpen MM, van Wikselaar P, Houweling-Tan B, Scaccia N, van Hal JW, Huijgen WJJ, Cone JW, Lopez-Contreras AM (2016) Biorefinery of the green seaweed Ulva lactuca to produce animal feed, chemicals and biofuels. J Appl Phycol 28:3511-3525

BIPM, IEC, IFCC, ILAC, ISO, IUPAC, IUPAP, OIML (2008) Evaluation of measurement data - guide to the expression of uncertainty in measurement. BIPM Joint Committee for Guides in Metrology, Paris, France. JCGM 100:2008 (GUM 1995 with Minor Corrections))

Chandel AK, Garlapati VK, Singh AK, Antunes FAF, da Silva SS (2018) The path forward for lignocellulose biorefineries: bottlenecks, solutions, and perspective on commercialization. Bioresour Technol 264:370-381

Creed JC, Kain JM, Norton TA (1998) An experimental evaluation of density and plant size in two large brown seaweeds. J Phycol 34:3952

Enquist-Newman M, Faust AME, Bravo DD, Santos CNS, Raisner RM, Hanel A, Sarvabhowman P, Le C, Regitsky DD, Cooper SR, Peereboom L, Clark A, Martinez Y, Goldsmith J, Cho MY, Donohoue PD, Luo L, Lamberson B, Tamrakar P, Kim EJ, Villari JL, Gill A, Tripathi SA, Karamchedu P, Paredes CJ, Rajgarhia V, Kotlar HK, Bailey RB, Miller DJ, Ohler NL, Swimmer C, Yoshikuni Y (2014) Efficient ethanol production from brown macroalgae sugars by a synthetic yeast platform. Nature 505:239-243

European commission (2006) Comission regulation (EC) No 1881/2006 of 19 December 2006 setting maximum levels for certain contaminants in foodstuffs. Revised 2 November 2019. Off J Eur Union L364

European commission (2008) Commission regulation (EC) No 889/2008 of 5 September 2008 laying down detailed rules for the implementation of Council Regulation (EC) No 834/2007 on organic production and labelling of organic products with regard to organic production, labelling and control. Revised 12 November 2018. Off J Eur Union L250

European commission (2014) Regulation (EU) No 1143/2014 of the European Parliament and of the Council of 22 October 2014 on the prevention and management of the introduction and spread of invasive alien species. Revised 4 November 2014. Off J Eur Union L317

FAO (2015) Global statistical collections - Global aquaculture production. Fisheries and Aquaculture Organisation of the United Nations, Rome. http://www.fao.org/fishery/statistics/global-aquacultureproduction/en; Accessed 9 February 2018

Fiset C, Liefer J, Irwin AJ, Finkel ZV (2017) Methodological biases in estimates of macroalgal macromolecular composition. Limnol Oceanogr-Meth 15:618-630

Fleurence J (2004) Seaweed proteins. In: Yada RY (ed) Proteins in food processing. Woodhead Publishing, Cambridge, pp 197-213

Galland-Irmouli AV, Fleurence J, Lamghari R, Lucon M, Rouxel C, Barbaroux O, Bronowicki JP, Villaume C, Gueant JL (1999) Nutritional value of proteins from edible seaweed Palmaria palmata (Dulse). J Nutr Biochem 10:353-359

Graiff A, Ruth W, Kragl U, Karsten U (2016) Chemical characterization and quantification of the brown algal storage compound laminarin-a new methodological approach. J Appl Phycol 28:533-543

Grand View Research (2016) Mannitol market analysis by application (food additive, pharmaceuticals, industrial, surfactants) and segment forecasts to 2024. Research GV, San Francisco, United States. 9781-68038-900-5 pp 1-115

Guiry MD, Guiry GM (2018) Algaebase. World-wide electronic publication, National University of Ireland, Galway. http://www.algaebase. org; Accessed 14 June 2018
Guiry MD, Morrison L (2013) The sustainable harvesting of Ascophyllum nodosum (Fucaceae, Phaeophyceae) in Ireland, with notes on the collection and use of some other brown algae. J Appl Phycol 25:1823-1830

Handa A, Forbord S, Wang XX, Broch OJ, Dahle SW, Storseth TR, Reitan KI, Olsen Y, Skjermo J (2013) Seasonal- and depthdependent growth of cultivated kelp (Saccharina latissima) in close proximity to salmon (Salmo salar) aquaculture in Norway. Aquaculture 414:191-201

Harrysson H, Hayes M, Eimer F, Carlsson N-G, Toth GB, Undeland I (2018) Production of protein extracts from Swedish red, green, and brown seaweeds, Porphyra umbilicalis Kützing, Ulva lactuca Linnaeus, and Saccharina latissima (Linnaeus) J. V. Lamouroux using three different methods J Appl Phycol 30:3565-3580

Havs- och vattenmyndigheten (2019) Marina miljöövervakningsdata. sharkweb.smhi.se

Holdt SL, Kraan S (2011) Bioactive compounds in seaweed: functional food applications and legislation. J Appl Phycol 23:543-597

Hou XR, Hansen JH, Bjerre AB (2015) Integrated bioethanol and protein production from brown seaweed Laminaria digitata. Bioresour Technol 197:310-317

Hurd CL, Harrison PJ, Bischof K, Lobban CS (2014a) Adsorption, uptake, accumulation and biomonitors. In: Seaweed ecology and physiology. Cambridge University Press, Cambridge, pp 380-383

Hurd CL, Harrison PJ, Bischof K, Lobban CS (2014b) Nutrients. In: Seaweed ecology and physiology. Cambridge University Press, Cambridge, pp 238-293

Johannesson K (1989) The bare zone of Swedish rocky shores-why is it there? Oikos 54:77-86

Jung KA, Lim SR, Kim Y, Park JM (2013) Potentials of macroalgae as feedstocks for biorefinery. Bioresour Technol 135:182-190

Karr-Lilienthal LK, Bauer LL, Utterback PL, Zinn KE, Frazier RL, Parsons CM, Fahey GC (2006) Chemical composition and nutritional quality of soybean meals prepared by extruder/expeller processing for use in poultry diets. J Agr Food Chem 54:8108-8114

Khairy HM, El-Shafay SM (2013) Seasonal variations in the biochemical composition of some common seaweed species from the coast of Abu Qir Bay, Alexandria, Egypt. Oceanologia 55:435-452

Kim M, Day DF (2011) Composition of sugar cane, energy cane, and sweet sorghum suitable for ethanol production at Louisiana sugar mills. J Ind Microbiol Biot 38:803-807

Klass DL (1998) Photosynthesis of biomass and its conversion-related properties. In: Biomass for renewable energy, fuels, and chemicals. Academic Press, San Diego. pp 51-90

Konda NVSN, Singh S, Simmons BA, Klein-Marcuschamer D (2015) An investigation on the economic feasibility of macroalgae as a potential feedstock for biorefineries. Bioenerg Res 8:1046-1056

Lahaye M, Robic A (2007) Structure and functional properties of ulvan, a polysaccharide from green seaweeds. Biomacromolecules 8:17651774

Liljenström S (2018) Seaweed for the future. University of Gothenburg, Gothenburg. https://sweaweed.gu.se/; searched on 12 June 2018

Maehre HK, Malde MK, Eilertsen KE, Elvevoll EO (2014) Characterization of protein, lipid and mineral contents in common Norwegian seaweeds and evaluation of their potential as food and feed. J Sci Food Agr 94:3281-3290

Magnusson M, Carl C, Mata L, de Nys R, Paul NA (2016) Seaweed salt from Ulva: a novel first step in a cascading biorefinery model. Algal Res 16:308-316

Manns D, Deutschle AL, Saake B, Meyer AS (2014) Methodology for quantitative determination of the carbohydrate composition of brown seaweeds (Laminariaceae). RSC Adv 4:25736-25746

Manns D, Nielsen M, Bruhn A, Saake B, Meyer A (2017) Compositional variations of brown seaweeds Laminaria digitata and Saccharina latissima in Danish waters. J Appl Phycol 29:1493-1506 
Marinho GS, Alvarado-Morales M, Angelidaki I (2016) Valorization of macroalga Saccharina latissima as novel feedstock for fermentation-based succinic acid production in a biorefinery approach and economic aspects. Algal Res 16:102-109

Marinho GS, Holdt SL (2017) Nitrogen-to-protein conversion factor of seaweed varies with season. In: Book of Abstracts Sustain 2017 [Sustain Abstract F-2]. Technical University of Denmark (DTU), Kgs. Lyngby, Denmark

Martone PT, Estevez JM, Lu FC, Ruel K, Denny MW, Somerville C, Ralph J (2009) Discovery of lignin in seaweed reveals convergent evolution of cell-wall architecture. Curr Biol 19:169-175

Matsson S, Christie H, Fieler R (2019) Variation in biomass and biofouling of kelp, Saccharina latissima, cultivated in the Arctic, Norway. Aquaculture 506:445-452

Milledge JJ, Smith B, Dyer PW, Harvey P (2014) Macroalgae-derived biofuel: a review of methods of energy extraction from seaweed biomass. Energies 7:7194-7222

Morrissey J, Kraan S, Guiry MD (2001) A guide to commercially important seaweeds on the Irish coast. Bord Iascaigh Mhara/Irish Sea Fisheries Board, Dublin, Ireland, pp 1-67

Nielsen MM, Manns D, D'Este M, Krause-Jensen D, Rasmussen MB, Larsen MM, Alvarado-Morales M, Angelidaki I, Bruhn A (2016) Variation in biochemical composition of Saccharina latissima and Laminaria digitata along an estuarine salinity gradient in inner Danish waters. Algal Res 13:235-245

Niu WJ, Huang GQ, Liu X, Chen LJ, Han LJ (2014) Chemical composition and calorific value prediction of wheat straw at different maturity stages using near-infrared reflectance spectroscopy. Energ Fuels 28:7474-7482

Nordic Council of Ministers (2012) Nordic nutrition recommendations 2012-integrating nutrition and physical activity. Narayana Press, Copenhagen. p 627. doi:https://doi.org/10.6027/Nord2014-002, Nordic Nutrition Recommendations 2012

Overland M, Mydland LT, Skrede A (2019) Marine macroalgae as sources of protein and bioactive compounds in feed for monogastric animals. J Sci Food Agr 99:13-24

Parjikolaei B, Bruhn A, Eybye K, Larsen M, Rasmussen M, Christensen K, Fretté X (2016) Valuable biomolecules from nine North Atlantic red macroalgae: amino acids, fatty acids, carotenoids, minerals and metals. Nat Resour 7:157-183

Pettersen RC (1984) The chemical composition of wood. In: Rowell RM (ed) The chemistry of solid wood. American Chemical Society, Washington, pp 57-126

Pochon X, Atalah J, Wood SA, Hopkins GA, Watts A, Boedeker C (2015) Cladophora ruchingeri (C. Agardh) Kutzing, 1845 (Cladophorales, Chlorophyta): a new biofouling pest of greenlipped mussel Perna canaliculus (Gmelin, 1791) farms in New Zealand. Aquat Invas 10:123-133

Rae A, Bonnet G (2013) Sugarcane compositional analysis to enable food safety assessment of modified varieties. CSIRO Plant Industry, St. Lucia, Australia. CPI020 pp 1-36

Raikova S, Le CD, Beacham TA, Jenkins RW, Allen MJ, Chuck CJ (2017) Towards a marine biorefinery through the hydrothermal liquefaction of macroalgae native to the United Kingdom. Biomass Bioenergy 107:244-253

Rioux LE, Turgeon SL (2015) Seaweed carbohydrates. In: Tiwari BK, Troy DJ (eds) Seaweed sustainability. Academic Press, Oxford, pp 141-192
Rueness J (1977) Norsk algeflora. Universitetsforlaget, Oslo

Schiener P, Black KD, Stanley MS, Green DH (2015) The seasonal variation in the chemical composition of the kelp species Laminaria digitata, Laminaria hyperborea, Saccharina latissima and Alaria esculenta. J Appl Phycol 27:363-373

Skoglund N, Werner K, Nylund GM, Pavia H, Albers E, Brostrom M (2017) Combustion of seaweed-a fuel design strategy. Fuel Process Technol 165:155-161

Stiger-Pouvreau V, Jegou C, Cerantola S, Guerard F, Le Lann K (2014) Phlorotannins in sargassaceae species from Brittany (France): interesting molecules for ecophysiological and valorisation purposes. In: Bourgougnon N (ed) Sea plants. Academic Press Ltd-Elsevier Science Ltd, London, pp 379-411

Taylor R, Fletcher RL, Raven JA (2001) Preliminary studies on the growth of selected 'Green tide' algae in laboratory culture: effects of irradiance, temperature, salinity and nutrients on growth rate. Bot Mar 44:327-336

Thomas J-BE (2018) Insights on the sustainability of a Swedish seaweed industry. PhD Thesis, KTH Royal Institute of Technology, Sweden $64 \mathrm{p}$

Troger N, Richter D, Stahl R (2013) Effect of feedstock composition on product yields and energy recovery rates of fast pyrolysis products from different straw types. J Anal Appl Pyrol 100:158-165

University of Gothenburg (2014) Sea water systems Tjärnö. University of Gothenburg, Gothenburg. https://loven.gu.se/english/Study+and+ work/sea-water-systems/tjarno . Accessed 7 May 2018

van den Burg SWK, van Duijn AP, Bartelings H, van Krimpen MM, Poelman M (2016) The economic feasibility of seaweed production in the North Sea. Aquacult Econ Manag 20:235-252

van Hal JW, Huijgen WJJ, Lopez-Contreras AM (2014) Opportunities and challenges for seaweed in the biobased economy. Trends Biotechnol 32:231-233

van Wychen S, Laurens LML (2015) Determination of total carbohydrates in algal biomass laboratory analytical procedure (LAP). NREL, Denver, Colorado. NREL/TP-5100-60957 pp 1-14

Van Wychen S, Long W, Black SK, Laurens LML (2017) MBTH: a novel approach to rapid, spectrophotometric quantitation of total algal carbohydrates. Anal Biochem 518:90-93

Vilg JV, Nylund GM, Werner T, Qvirist L, Mayers JJ, Pavia H, Undeland I, Albers E (2015) Seasonal and spatial variation in biochemical composition of Saccharina latissima during a potential harvesting season for Western Sweden. Bot Mar 58:435-447

Yanagisawa M, Kawai S, Murata K (2013) Strategies for the production of high concentrations of bioethanol from seaweeds. Production of high concentrations of bioethanol from seaweeds. Bioengineered 4: 224-235

Young EB, Dring MJ, Savidge G, Birkett DA, Berges JA (2007) Seasonal variations in nitrate reductase activity and internal $\mathrm{N}$ pools in intertidal brown algae are correlated with ambient nitrate concentrations. Plant Cell Environ 30:764-774

Zinoun M, Deslandes E, Cosson J (1990) Chemical and spectrosopic analysis of phycocolloid extracts from Dilsea carnosa (Rhodophyceae, Cryptonemiales). Cryptogam Algol 11:257-263

Publisher's note Springer Nature remains neutral with regard to jurisdictional claims in published maps and institutional affiliations. 